\title{
Life histories predict genetic diversity and population structure within three species of octopus targeted by small- scale fisheries in Northwest Mexico
}

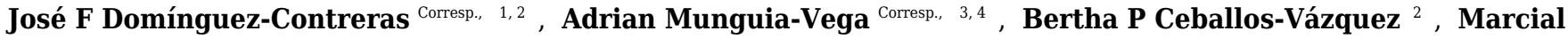 \\ Arellano-Martínez ${ }^{2}$, Francisco J García-Rodríguez ${ }^{2}$, Melanie Culver ${ }^{3,5}$, Hector Reyes-Bonilla ${ }^{1}$ \\ 1 Departamento Académico de Ciencias Marinas y Costeras, Universidad Autónoma de Baja California Sur, La Paz, Baja California Sur, Mexico \\ 2 Instituto Politécnico Nacional, La Paz, Baja California Sur, Mexico \\ 3 Conservation Genetics Laboratory, School of Natural Resources and Environment, University of Arizona, Tucson, Arizona, United States \\ 4 Comunidad y Biodiversidad A. C., Guaymas, Sonora, Mexico \\ 5 U.S. Geological Survey, Arizona Cooperative Fish and Wildlife Research Unit, School of Natural Resources \& Environment, University of Arizona, Tucson, \\ Arizona, United States \\ Corresponding Authors: José F Domínguez-Contreras, Adrian Munguia-Vega \\ Email address: fradoco@gmail.com, airdrian@email.arizona.edu
}

The fishery for octopus in Northwest Mexico has increased to over 2,000 tons annually, but to date the specific composition of the catch has been ignored. With at least three main species targeted by artisanal fisheries in the region with distinct life histories, the lack of basic biological information about the distribution, metapopulation size and structure of each species could impede effective fisheries management to avoid overexploitation. We tested if different life histories of three species of octopus could help predict observed patterns of genetic diversity, population dynamics, structure and connectivity and how this information could be relevant to the sustainable management of the fishery. We sequenced two mitochondrial genes and genotyped seven nuclear microsatellite loci to identify the distribution of each species in 20 locations from the Gulf of California and the west coast of the Baja California peninsula. We tested five hypotheses derived from population genetic theory based on differences in the fecundity and dispersal potential for each species. We discovered that Octopus bimaculoides with low fecundity and direct development (without a planktonic phase) had lower average effective population size and genetic diversity, but higher levels of kinship, population structure, and richness of private alleles, than the other two species. These features indicated limited dispersal and high local recruitment. In contrast, $O$. bimaculatus and $O$. hubbsorum with higher fecundity and planktonic phase as paralarvae had higher effective population size and genetic diversity, and overall lower kinship and population structure than 0 . bimaculoides. These observations supported higher levels of gene flow over a larger geographical scale. $O$. bimaculatus with the longest planktonic paralarval duration and therefore larger dispersal potential had differences in the calculated parameters possibly associated with increased 
connectivity. We propose $O$. bimaculoides is more susceptible to over exploitation of small, isolated populations and could have longer recovery times than the other two species. This species may benefit from distinct fishery management within each local population. $O$. bimaculatus and $O$. hubbsorum may benefit from fishery management that takes into account metapopulation structure over larger geographic scales and the directionality and magnitude of larval dispersal driven by ocean currents and population connectivity among individuals of each locality. The distribution of each species and variations in their reproductive phenology is also important to consider when establishing marine reserves or seasonal fishing closures. 
1 Life histories predict genetic diversity and population structure within three species of

2 octopus targeted by small-scale fisheries in Northwest Mexico

3

4 José F. Domínguez-Contreras ${ }^{1,2}$, Adrian Munguia-Vega ${ }^{3,4}$, Bertha P. Ceballos-Vázquez ${ }^{2}$,

5 Marcial Arellano-Martínez ${ }^{2}$, Francisco J. García-Rodríguez ${ }^{2}$, Melanie Culver ${ }^{5,3}$, and

6 Hector Reyes-Bonilla1.

$7{ }^{1}$ Departamento Académico de Ciencias Marinas y Costeras, Universidad Autónoma de Baja

8 California Sur, La Paz, Baja California Sur, México,

92 Instituto Politécnico Nacional, La Paz, Baja California Sur, México,

$10{ }^{3}$ Conservation Genetics Laboratory, School of Natural Resources and Environment, University

11 of Arizona, Tucson, Arizona, United States,

$12{ }^{4}$ Comunidad y Biodiversidad A.C., Guaymas, Sonora, México,

$13{ }^{5}$ U.S. Geological Survey, Arizona Cooperative Fish and Wildlife Research Unit, School of

14 Natural Resources \& Environment, University of Arizona, Tucson, Arizona, United States.

15

16 Corresponding Authors: José F Domínguez-Contreras, Adrian Munguia-Vega

17 Email address: fradoco@gmail.com, airdrian@email.arizona.edu 
19

20

21

22

\section{ABSTRACT}

The fishery for octopus in Northwest Mexico has increased to over 2,000 tons annually, but to date the specific composition of the catch has been ignored. With at least three main species targeted by artisanal fisheries in the region with distinct life histories, the lack of basic biological information about the distribution, metapopulation size and structure of each species could impede effective fisheries management to avoid overexploitation. We tested if different life histories of three species of octopus could help predict observed patterns of genetic diversity, population dynamics, structure and connectivity and how this information could be relevant to the sustainable management of the fishery. We sequenced two mitochondrial genes and genotyped seven nuclear microsatellite loci to identify the distribution of each species in 20 locations from the Gulf of California and the west coast of the Baja California peninsula. We tested five hypotheses derived from population genetic theory based on differences in the fecundity and dispersal potential for each species. We discovered that Octopus bimaculoides with low fecundity and direct development (without a planktonic phase) had lower average effective population size and genetic diversity, but higher levels of kinship, population structure, and richness of private alleles, than the other two species. These features indicated limited dispersal and high local recruitment. In contrast, O. bimaculatus and $O$. hubbsorum with higher fecundity and planktonic phase as paralarvae had higher effective population size and genetic diversity, and overall lower kinship and population structure than $O$. bimaculoides. These observations supported higher levels of gene flow over a larger geographical scale. $O$. bimaculatus with the longest planktonic paralarval duration and therefore larger dispersal potential had differences in the calculated parameters possibly associated with increased connectivity. We propose $O$. bimaculoides is more susceptible to over exploitation of small, 
42 isolated populations and could have longer recovery times than the other two species. This

43 species may benefit from distinct fishery management within each local population. $O$.

44 bimaculatus and $O$. hubbsorum may benefit from fishery management that takes into account

45 metapopulation structure over larger geographic scales and the directionality and magnitude of

46 larval dispersal driven by ocean currents and population connectivity among individuals of each

47 locality. The distribution of each species and variations in their reproductive phenology is also

48 important to consider when establishing marine reserves or seasonal fishing closures. 
49

50

51

52

53

54

55

56

57

58

59

60

61

62

63

64

65

66

67

68

69

70

71

\section{INTRODUCTION}

As fish catches are collapsing around the world, the focus of commercial fisheries has shifted to resources within lower trophic levels, but with similar or higher economic revenues (Pauly et al. 2002; Sala et al. 2004; Watson \& Pauly 2001). Cephalopods are a marine resource with lower trophic levels capable of supporting the substantial expansion of fisheries landings (Arkhipkin et al. 2015; Doubleday et al. 2016). Therefore fishing pressure is expected to increase in the near future as a response to growing demands of marine resources associated with increase of global human population (Hunsicker et al. 2010). Cephalopods account for about $20 \%$ of the fisheries landing in the world, mainly comprised of squids (FAO 2015). Octopus catches targeted by small-scale fisheries have increased considerably from $1970(\sim 3,000$ ton/year) to 2017 ( $\sim 60,000$ ton/year) and its commercial value is sometimes higher than squids (FAO 2015).

During 2003 - 2013 most of the global production (80\%) was caught in Mexico (36\%), Spain (17\%), Portugal (15\%), Italy (12\%) (FAO 2015). In Mexico O. maya (Voss and Solís-Ramírez, $1966)$ is the most economically important species captured along the Atlantic coast (NOM-008PESC-1993; Jurado-Molina 2010).

At least 10 different octopus species have been described in the Mexican Pacific, including O. bimaculatus (Verrill 1883), O. chierchiae (Jatta 1889), O. digueti (Perrier and Rocheburne 1894), O. bimaculoides (Pickford and McConnaughey 1949), and Berry’s (1953) octopuses: O. alecto, O. fitchi, O. hubbsorum, O. veligero, O. rubescens and O. penicillifer (Brusca 1980; Gotshall 1998; Hochberg \& Fields 1980; Norman \& Hochberg 2005; Roper et al. 1995). Recent studies indicate that likely three species contribute most of the catch volume in the

Pacific coast of Mexico, namely O. hubbsorum (Alejo-Plata et al. 2009; Domínguez-Contreras et al. 2013; López-Uriarte et al. 2005), O. bimaculatus (López-Rocha et al. 2012; Villegas et al. 
72 2014), and O. bimaculoides (González-Meléndez 2012). In Northwest Mexico, the octopus

73 fishery represents an important income for small-scale fishers that sell the catch locally or in commercial markets (Finkbeiner 2015; Finkbeiner \& Basurto 2015; Moreno-Báez et al. 2012). However, it still unclear which species contribute to the catch in different localities because official fishery statistics do not attempt to distinguish different species. During 2014, official reports indicate that artisanal fishery operating along Norwest Mexico produced at least $\sim 2,000$ tons of octopus worth $\sim 350,000$ USD (CONAPESCA 2014). Most capture of octopus in this region takes place in the Gulf of California year-round via hooka diving with an air compressor or using traps. In the past, it was suggested that the fishery might be targeting at least two different species (O. bimaculatus and $O$. hubbsorum) (Moreno-Báez et al. 2012). The lack of species identification in octopus fisheries reports is due to their dynamic biological behavior and ability to change color, pattern, texture and shape (Boyle \& vonBoletzky 1996). In addition, their anatomy includes few hard structures that makes the species identification to the species level difficult for fishermen and fishery managers, especially in octopods (Hanlon 1988).

Ignoring which species are being fished, and their geographic distribution, could have serious detrimental consequences in the long-term, not only for local fisheries management but for the conservation of the species (Garcia-Vazquez et al. 2012). For example, without precise fishery monitoring, it could be impossible to estimate if a particular species or stock is being over or under exploited in a certain area (Marko et al. 2004). The problem of not identifying each species could be particularly serious if octopuses show contrasting life histories and population dynamics that may translate into distinct levels of maximum sustainable yield (MSY) and recovery times. Different life histories may require distinct management strategies during different seasons and over differing geographic scales. O. bimaculatus could potentially be 
95

96

97

98

99

100

101

102

103

104

105

106

107

108

109

110

111

112

113

114

115

116

117

sympatric with $O$. bimaculoides in the west coast of the Baja California peninsula, while $O$. bimaculatus could potentially overlap its geographic distribution with $O$. hubbsorum in the Gulf of California (Table 1). The reproductive season is different for each species, and the three species differ in their fecundity, egg size and planktonic paralarval duration (PPD) (Table 1). Octopus bimaculoides spawns hundreds of large eggs and lacks a paralarval stages and therefore does not pass through a planktonic phase. O. hubbsorum lays thousands of smaller-sized eggs and the PPD is probably similar to $O$. vulgaris based on the size of its eggs ( $\sim 60$ days, Iglesias et al. 2007). O. bimaculatus lays thousands of medium-sized eggs and shows a relatively longer PPD (up to 90 days) than $O$. hubbsorum and O. bimaculoides (Table 1). The three species have life spans lasting between 1.5 and 2 years and males typically have smaller size at sexual maturity than females (Table 1).

Our main hypothesis is that differences in the life history among the three octopus species from Northwest Mexico could translate into distinct patterns of genetic diversity, population dynamics, structure and larval connectivity relevant for sustainable fisheries management. We used two mitochondrial DNA markers and seven nuclear microsatellite loci, informative for the three species, to infer relevant differences in population parameters and evolutionary processes among species. We first established the geographic distribution of each species through genetic identification of tissue samples collected over the study area. Later, five a priori hypotheses were tested based on the fecundity and potential for paralarval dispersal reported in the scientific literature for each species derived from theoretical and empirical population genetic studies regarding expected effective population size, genetic diversity, genetic relatedness within populations (kinship) and population structure (Table 1,2). We discuss implications of our results for fisheries management of the three species in Northwest Mexico. 


\section{MATERIALS \& METHODS}

\section{Sample collection and DNA extraction}

We obtained 316 tissue samples of octopus (arm tissue) collected between 2008 and 2013

121 from 20 localities in both coasts of the Baja California peninsula, including the Northeast coast

122 of the Gulf of California (Field experiments were approved by Secretaría de Agricultura,

123 Ganadería, Desarrollo Rural, Pesca y Alimentación, SAGARPA No.

124

PPF/DGOPA.09151.260809.2885 and PPF/DGOPA-224/16) (Fig.1). The field sampling took

place mainly during spring and summer (Table S1) at fishing communities with the help of

small-scale fishers. Octopuses were collected at seven locations along the west coast of the Baja

California peninsula, (Ejido Erendira close to Ensenada, Baja California down to El Conejo in

Baja California Sur) and 13 sites from the central (Santa Rosalía) and northern Gulf of California

129

130

131

132

133

134

135

136

137

138

139

(from the northern tip of Bahía de Los Angeles and Isla Tiburón up to Puerto Peñasco), including the Midriff islands. The Midriff islands include many islands and islets in the northern Gulf of California (Fig. 1). Several locations are remote and with difficult access, therefore had smaller samples sizes, while others localities with low number of samples was due to the difficulty of catching octopuses outside their reproductive season. We distinguished between $O$. bimaculatus and $O$. bimaculoides based on distinctive characteristics of the gonads of mature females using criteria described by Pickford \& MacConnaughey (1949). O. hubbsorum was identified using morphological traits described by Domínguez-Contreras et al. (2013) and original descriptions of Berry (1953). Tissue samples were stored in $96 \%$ ethanol in the field and $-20{ }^{\circ} \mathrm{C}$ in the lab. We extracted DNA using the DNeasy blood and tissue kit (QIAGEN, Valencia, CA, U.S.) following the manufacturer specifications. 


\section{Mitochondrial DNA sequencing}

We amplified two fragments of mitochondrial genes for a subset of the samples to detect

143 the presence of each species at representative locations and to control for the differential success

144 of cross-amplifying microsatellite loci (see below). We selected 97 individuals from 13

145 localities, including 8 individuals per locality except for Puerto Refugio which had one sample

146 analyzed. We targeted the large ribosomal subunit rRNA (16S) gene employing primers L1987

147 5'-GCCTCGCCTGTTTACCAAAAAC-3' and H2609 5'-CGGTCTGAACTCAGATCACGT-3'

148 (Palumbi et al. 1991) and the Cytochrome Oxidase subunit 1 (COI) gene with primers LCO 1490

149 5'-GGTCAAACAAATCATAAAGATATTGG-3' and HCO2198 5'-

150 TAAAATTCAGGGTGACCAAAAAATCA-3' (Folmer et al. 1994). We used 25 $\mu$ L volume

151 PCRs reactions with 15 - 40 ng genomic DNA, $1 \times$ PCR buffer, $0.2 \mathrm{mM}$ each dNTP, $2 \mathrm{mM}$

$152 \mathrm{MgCl}_{2}, 0.2 \% \mathrm{BSA}, 1 \mathrm{U}$ Taq DNA polymerase (Invitrogen) and $0.5 \mu \mathrm{M}$ of each primer for both

153 markers. PCR thermo-cycling consisted of denaturation at $94{ }^{\circ} \mathrm{C}$ for $2 \mathrm{~min}, 30$ cycles of $94{ }^{\circ} \mathrm{C}$

154 for $1 \mathrm{~min}$, annealing at $51{ }^{\circ} \mathrm{C}(\mathrm{COI})$ or $45.5^{\circ} \mathrm{C}\left(16 \mathrm{~s}\right.$ rDNA) for $1 \mathrm{~min}$, and extension at $72{ }^{\circ} \mathrm{C}$ for

$1552 \mathrm{~min}$, followed by a final extension of $72^{\circ} \mathrm{C}$ for $7 \mathrm{~min}$. PCR products were purified using

156 ExoSAP (Affimetrix, INC) and both strands were sequenced on an Applied Biosystems 3730XL

157 DNA Analyzer at the University of Arizona Genetics Core (UAGC).

Genotyping of microsatellites markers

We tested 15 microsatellite markers developed for O. bimaculatus (Domínguez-Contreras et al. 2014) and based on PCR amplification success selected seven unlinked microsatellites

161 (Ocbi25, Ocbi35, Ocbi39, Ocbi41, Ocbi47, Ocbi48, and Ocbi50) that were polymorphic and 
162 informative among the three octopus species. We genotyped 316 samples following PCR

163 methods previously described (Domínguez-Contreras et al. 2014). PCR products were sized on

164 an Applied Biosystems 3730XL DNA Analyzer at the University of Arizona's UAGC Core

165 Facility. Microsatellite electropherograms were scored using GeneMarker Version 2.6.0

166 (SoftGenetics LLC). Allele sizes were assigned into bins using FLEXIBIN (Amos et al. 2007).

167 Deviations from Hardy-Weinberg equilibrium (HWE) were estimated using GENEPOP 4.2

168 (Raymond \& Rousset 1995). We used MICROCHECKER 2.2.3 to test for genotyping errors and 169 presence of null alleles (Van Oosterhout et al. 2004).

\section{Species identification}

We used the mitochondrial sequences and microsatellite genotypes to identify species for each sampled individual using phylogenetic analyses of sequence data and Bayesian assignment analyses of microsatellite genotypes. The 16S rDNA and COI sequences were edited using

174 Chromas Pro Version 1.6 and aligned using MUSCLE multiple alignment tools implemented in Mega6 (Tamura et al. 2013). We used JmodelTest 2 (Darriba et al. 2012; Guindon \& Gascuel 2003 ) to select the best fit model of nucleotide substitution for phylogenetic analyses using the

177 Akaike and Bayesian information criteria. We applied the Jukes-Cantor (JC) model with 1,000 bootstraps to estimate genetic distances and constructed a Neighbor-joining (NJ) tree using 10,000 bootstraps replications in MEGA (Tamura et al. 2013).

STRUCTURE version 2.3.4 (Pritchard et al. 2000) was used to analyze microsatellite genotypes using admixture and without prior location information, with allele frequencies

182 correlated among populations. We used a duration of the burnin period of $1 \times 10^{6}$, a number of $183 \mathrm{MCMC}$ repeats after burnin of $2 \times 10^{6}$, with 10 iterations for each number of genetic clusters $(\mathrm{K})$, 
184 and K assumed to vary between 1 and 20. To determine the optimal number of K, we selected

185 the number of clusters by looking at the highest likelihood values (mean of 10 iterations) as well

186 as the highest $\Delta \mathrm{K}$ value implemented in the online software CLUMPAK (Kopelman et al. 2015).

187 We used both values because some evidence has suggested the likelihood method is not always

188 accurate (Evanno et al. 2005). The value of $\Delta \mathrm{K}$ is based on the rate of change in the log

189 probability of data between successive $\mathrm{K}$ values, which provides a relatively better estimate of

190 the number of genetic clusters (Evanno et al. 2005). We used the following criteria to assign

191 individuals to species according the their microsatellite genotypes: First, we excluded those

192 samples that showed missing data at two or more loci. Second, we used a majority rule requiring

193 at least $2 / 3(66.66 \%)$ of the probability of assignment to any of the three species, and excluded

194 those individuals where this criterion was not met. Third, we only included individuals where the

195 microsatellite and the mitochondrial data agreed on species assignment.

Genetic diversity and effective population size within species

198

199

200

201

202

203

204

205

The neutral theory of molecular evolution predicts that in a panmictic population of constant size genetic diversity should be proportional to the effective size of the population (Kimura 1983).

This is because in an idealized, panmictic, population the rate of loss of neutral alleles via genetic drift is inversely proportional to the population size (Charlesworth 2009). Based on recent comparative studies of octopuses, we expect that species with high brood sizes to produce relatively small eggs (O. bimaculatus and $O$. hubbsorum $)$ and will have higher genetic diversity and effective population size than species with comparatively low-fecundity that produce a small number of relatively large eggs (O. bimaculoides) (Table 2) (Ellegren \& Galtier 2016; Romiguier 
206 et al. 2014). We calculated the number of alleles $\left(\mathrm{N}_{\mathrm{A}}\right)$, effective number of alleles $\left(\mathrm{N}_{\mathrm{E}}\right.$, which

207 takes into account different sample sizes among localities), expected heterozygosity $\left(\mathrm{H}_{\mathrm{E}}\right)$ and

208 observed heterozygosity $\left(\mathrm{H}_{\mathrm{O}}\right)$ with GENALEX 6.501 (Peakall \& Smouse 2012) to evaluate

209 genetic diversity from the microsatellite data. Allelic richness $\left(\mathrm{R}_{\mathrm{A}}\right)$ was estimated using HP-Rare

210 to correct for differences in sample size among locations (Kalinowski 2005).

211 Private alleles (alleles that are unique to one population) are expected to be more frequent in 212 genetically isolated populations, while their frequency should be considerably lower in well-

213 connected populations (Beger et al. 2014; Munguía-Vega et al. 2015). If we extend this process

214 to populations within each species, then populations of species with limited opportunities for

215 dispersal (direct ontogenetic development, O. bimaculoides) should show higher frequency of

216 private alleles than species with a pelagic paralarval stage (Table 2). Private allelic richness

$217\left(\mathrm{R}_{\mathrm{PA}}\right)$ was estimated using HP-Rare to correct for different sample sizes. We estimated a global

218 contemporary effective size $\left(N_{e}\right)$ for each species via the linkage disequilibrium method with a

219 bias correction and a lower allele frequency of 0.05 and 0.02 , and with the molecular coancestry

220 method as implemented in the software NE-ESTIMATOR V2 (Do et al. 2014).

221

222

\section{Genetic structure within species}

Species with a long PPD are expected to disperse in a larger area than species with brief

or absent PPD (e.g. direct ontogenetic development) (Shanks 2009). Consequently, $O$.

225 bimaculoides with direct development $(\mathrm{PPD}=0)$ should show higher genetic structure (e.g.

226 global $\left.F_{S T}\right)$ (Riginos \& Liggins 2013), than O. hubbsorum with short PPD and O. bimaculatus

227 with long PPD (Table 2) (Selkoe et al. 2014; Selkoe \& Toonen 2011). We conducted a

228 hierarchical analysis of molecular of variance (AMOVA) using 999 permutations in GENALEX 
229 6.501(Peakall \& Smouse 2012) to estimate the genetic differences observed within and among

230 populations; in other words to estimate genetic structure. We used FreeNA to measure the effect

231 of null alleles on $F_{S T}$ estimates of population structure, taking into account the frequency of null

232 alleles estimated with the expectation maximization method (EM) (Chapuis \& Estoup 2007).

233

Genetic relatedness within populations of each species

235

236

237

238

239

240

241

242

243

244

245

246

247

248

249

250

The magnitude of local paralarval retention, or the proportion of paralarvae produced within a site that remain in that site, is expected to increase the degree of genetic relatedness $(R)$ within populations (Burgess et al. 2014; Christie et al. 2010). We expect that species with direct ontogenetic development $(\mathrm{PPD}=0$, O. bimaculoides $)$ should have a higher probability for individuals to remain near their hatching site, and thus to show higher levels of genetic relatedness or kinship within populations than the other two species with a planktonic paralarval drift (Table 2). Since local retention is expected to decrease with increasing PPD (Byers \& Pringle 2006), we expect that genetic relatedness within populations will be lower in the species with the longest known PPD (O. bimaculatus). We used Queller \& Goodnight (1989) relatedness metric to calculate pairwise relatedness to describe the number of alleles shared between pairs of individuals and then calculated the average within each population as implemented in GenAlex 6.2 (Peakall \& Smouse 2012). Statistical significance was assessed by 9,999 permutations and 10,000 bootstraps to estimate $95 \%$ confidence intervals around the hypothesis of random mating.

\section{RESULTS}

Species identification 
A total of $1054 \mathrm{bp}$ were sequenced for 97 individual samples, including $473 \mathrm{bp}$ from the

252

253

254

255

256

257

258

259

260

261

262

263

264

265

266

267

268

269

270

271

272

273

16S rRNA gene and 581 bp from the COI gene (GenBank Accession numbers KY985098 -

KY985194 for 16S, and KY985005 - KY985097 for COI). The optimum model of substitution

according to the Akaike and Bayesian criteria was JC for both 16S rRNA and COI. The resulting

NJ of 16S rRNA and COI genes showed the monophyletic status of the three species $O$.

bimaculatus, O. bimaculoides and O. hubbsorum (Fig 2 A). O. bimaculoides was present in locations from the west coast of Baja California Peninsula (Ejido Erendira, San Quintin, and Bahía Magdalena), but absent in the Gulf of California. O. bimaculatus was present at only one locality from the west coast of the Baja California Peninsula (Malarrimo) and in samples from the northern Gulf of California including Puerto Peñasco, Puerto Refugio, Puerto Lobos, San Luis Gonzaga, Bahía de los Ángeles and only one individual from Puerto Libertad evidenced with 16S rRNA, (no data was obtained for the COI sequence of this individual). O. hubbsorum was present in several localities from the northern Gulf of California (Puerto Libertad, Isla San Lorenzo, and Bahía Kino) and in the Central Gulf of California (Santa Rosalía) (Fig 2 A).

Nucleotide divergence between the three species ranged from $3.3-7.1 \%$ for the $16 \mathrm{~S}$ rRNA gene and from $6.3-10.4 \%$ for the COI gene (Table 3). Octopus bimaculoides showed less divergence with $O$. bimaculatus $(3.3 \%$ and $6.3 \%$, respectively) than with $O$. hubbsorum $(6.3 \%$ and $10.0 \%$, respectively). The largest divergence was observed between $O$. bimaculatus and $O$. hubbsorum (7.1\% and $10.4 \%$, respectively).

We genotyped seven microsatellite loci in 316 individuals collected from 20 localities and observed an average frequency of missing data of $3.75 \%$ (range $1.26-7.27$ ) by locus, and $3.84 \%$ (range $0-28.5$ ) by octopus individual. Hardy-Weinberg tests suggested significant deviations at only 7 out of 140 unique loci/location combinations tested without any clear pattern 
274 observed within locations or species (after Bonferroni correction P = 0.00036). Only Ocbi39,

275 Ocbi41 and Ocbi50 significantly deviated in 1, 2 and 4 locations from the 20 locations tested,

276 respectively $(\mathrm{P}=0.00036)$. The loci Ocbi41 and Ocbi50 were monomorphic in 1 and 6 localities,

277 respectively (Table S2). Except for the loci Ocbi35 and Ocbi41, the rest of the loci showed null

278 alleles in at least one locality, with Ocbi39 showing null alleles in 8 localities. The EM method

279 showed that average frequency of null alleles among all loci/locations varied from $0.000-0.108$,

280 for $O$. bimaculatus 0.025 (range $0.000-0.255$ ), for $O$. bimaculoides 0.026 (range $0.000-$

281 0.265), and for O. hubbsorum 0.041 (range $0.000-0.315$ ) (Table S3).

Before assigning individuals to species in order to test our five a-priori hypotheses we

283

284

285

286

287

288

289

290

291

292

293

294

295

296

excluded individuals that did not meet our criteria. We excluded 17 samples that showed missing data at two or more microsatellite loci. In our dataset, $92.78 \%$ of individuals assigned to one species using 16S rRNA and COI sequences (Fig. 2 A) were correctly assigned to the same species using microsatellite genotypes (Fig. 2 B). However, we found 20 individuals that did not comply with the $2 / 3$ rule of ancestry to a single species according to the nuclear genome and were excluded from further analyses. These individuals showed a shared ancestry between $O$. hubbsorum and O. bimaculatus, mainly in the localities of Puerto Peñasco, Puerto Refugio and Puerto Libertad (Table S4). These locations are within the limit of the geographic range between the two species (Table S5). In Puerto Peñasco, two cases were observed in which the mtDNA identified the individuals as $O$. bimaculatus, whereas their microsatellite ancestry assigned them to O. hubbsorum (Table S5).

The STRUCTURE analyses showed a modal frequency that supported the presence of at least two clusters or species $(\Delta \mathrm{K}=2$, Fig. S1A) according to the $\Delta \mathrm{K}$ method (Evanno et al. 2005). However, the highest mean value of the $\ln$ probability of data for $K=2$ (average $\ln [K]=$ 
$297-8362.29$, Fig. S1B) was close to $K=3$ (average $\ln [\mathrm{K}]=-8086.16$, Fig. S1B) in 10/10

298 repetitions, and in both cases the matrix of similarity scores produced by Clumpak among runs

299 aligned were identical 0.999 (Fig. S1C). The STRUCTURE bar plots (Fig 2 B) showed that K=

3003 clearly distinguished the three clusters or species previously identified in the phylogenetic

301 analyses of the mitochondrial markers and corresponding to $O$. bimaculoides $(\mathrm{N}=36), O$.

302 bimaculatus $(\mathrm{N}=140)$ and $O$. hubbsorum $(\mathrm{N}=101)$ among the 20 localities from Northwest

303 Mexico (Fig 2 B). Based on the STRUCTURE analyses, O. bimaculoides is found almost

304 exclusively in the west coast of the Baja California peninsula (Ejido Erendira, San Quintin, and

305 Bahía Magdalena), while the analyses suggested a few individuals inside the Gulf of California

306 were assigned to this species.

307 Octopus bimaculatus and O. hubbsorum were present in all the area of study. Octopus

308 bimaculatus was collected at La Bocana, Las Barrancas and Malarrimo, and O. hubbsorum in El

309 Conejo along the west coast of Baja California peninsula. In the Gulf of California, $O$.

310 bimaculatus was collected at Puerto Peñasco, San Luis Gonzaga, Isla Smith, Bahía de Los

311 Angeles and Puerto Lobos. Octopus hubbsorum was present in Puerto Libertad, Isla San

312 Lorenzo, Isla Tiburon, Bahía Kino, and Santa Rosalía (Fig. 2 C). STRUCTURE analyses

313 suggested the presence of individuals of $O$. bimaculatus and $O$. hubbsorum at Las Barrancas in

314 the west coast of Baja California peninsula and Puerto Peñasco, Puerto Refugio and Isla Tiburón 315 in the northern Gulf of California (Fig. 2 B, C).

316

317 Genetic diversity and effective population size within species

The seven loci were polymorphic for the three species (Table 4). Results generally 
320 with small eggs (O. bimaculatus and $O$. hubbsorum $)$ than in species that are less fecund and have

321 larger egg sizes (O. bimaculoides). We observed lower average levels of allelic diversity in $O$.

322 bimaculoides $\left(\mathrm{N}_{\mathrm{E}}=3.62 \pm 0.47, \mathrm{R}_{\mathrm{A}}=4.50 \pm 0.48\right)$ than in O. hubbsorum $\left(\mathrm{N}_{\mathrm{E}}=5.02 \pm 0.53, \mathrm{R}_{\mathrm{A}}\right.$

$323=4.54 \pm 0.12$ ), while results for $O$. bimaculatus were mixed and showed the largest diversity of

324 effective alleles $\left(\mathrm{N}_{\mathrm{E}}=5.64 \pm 0.28\right)$, and the lowest allelic richness $\left(\mathrm{R}_{\mathrm{A}}=4.14 \pm 0.07\right)$.

325 We observed that the species with direct ontogenetic development (O. bimaculoides) had

326 the largest average frequency of private alleles $\left(\mathrm{R}_{\mathrm{PA}}=1.60 \pm 0.48\right)$, compared to the species with

327 a planktonic paralarval phase (Table 4). The lowest values were observed in O. bimaculatus $\left(\mathrm{R}_{\mathrm{PA}}\right.$

$328=0.28 \pm 0.04)$, while $O$. hubbsorum showed intermediate values $\left(\mathrm{R}_{\mathrm{PA}}=0.69 \pm 0.19\right)$.

We observed the largest contemporary effective population size $N_{e}$ in O. bimaculatus

330

331

332

333

334

335

336

337

338

339

340

using both the linkage disequilibrium and the molecular coancestry methods (average LDNE $=$ $\left.190-252, \mathrm{M}_{\mathrm{C}}=\infty\right)$, followed by $O$. hubbsorum $\left(\mathrm{LDNE}=104-131, \mathrm{M}_{\mathrm{C}}=28.1\right) . O$.

bimaculoides had the lowest effective size according to the two methods $\left(\mathrm{LDNE}=10-18, \mathrm{M}_{\mathrm{C}}=\right.$ 10) (Table 5).

\section{Genetic structure within species}

Pooling sampling locations according to species molecular identification (Fig 1), we found that the microsatellite data AMOVA test supported the prediction that $O$. bimaculoides with direct ontogenetic development had higher levels of genetic structure $\left(F_{\mathrm{ST}}=0.19, P=\right.$ 0.000), compared to species with pelagic paralarvae (Table 6). Also, we accepted the hypothesis that $O$. bimaculatus, with the longest $\mathrm{PPD}$, had overall lower genetic structure $\left(F_{\mathrm{ST}}=0.09, P=\right.$ $0.000)$ compared with $O$. hubbsorum, with relatively shorter $\operatorname{PPD}\left(F_{\mathrm{ST}}=0.16, P=0.000\right)$. 
The frequency of null alleles can affect the estimates of genetic differentiation,

342 decreasing the genetic diversity and overestimating the $F_{\mathrm{ST}}$ values (Chapuis \& Estoup 2007).

343 Genetic differentiation with $\left(\right.$ Null $\left.F_{\mathrm{ST}}\right)$ and without $\left(F_{\mathrm{ST}}\right)$ null alleles estimated with FreeNA

344 were similar within each species: $O$. bimaculoides (Null $F_{\mathrm{ST}}=0.214$ and $\left.F_{\mathrm{ST}}=0.221\right), O$.

345 bimaculatus (Null $F_{\mathrm{ST}}=0.092$ and $F_{\mathrm{ST}}=0.088$, ) and $O$. hubbsorum $\left(\mathrm{Null} F_{\mathrm{ST}}=0.102\right.$ and $F_{\mathrm{ST}}=$ $346 \quad$ 0.110) (Table S6).

Genetic relatedness within populations of each species

The average genetic relatedness for three octopus species were significantly greater than expectations based on random mating (all values $\mathrm{p}=0.000$, Fig. 3). We found that $O$. bimaculoides with direct ontogenetic development (no paralarval planktonic stage) had the highest average relatedness within populations $(\mathrm{R}=0.209)$, followed by $O$. hubbsorum with intermediate PPD $(\mathrm{R}=0.135)$, while $O$. bimaculatus with the longest PPD had the lowest mean

354 level of relatedness $(\mathrm{R}=0.020)$.

\section{DISCUSSION}

We analyzed slowly evolving haploid markers (the mitochondrial genes 16S rRNA and $\mathrm{COI}$ ) and rapidly-evolving, hypervariable, nuclear markers (seven microsatellite loci) to infer the geographic distribution of three molecularly identified species of octopus among 20 fishing 
361 paralarval planktonic drift (or lack thereof) influence genetic diversity and population structure

362 found within each species.

363 A minimum of $3 \%$ genetic divergence in the COI gene is considered a threshold to

364 distinguish species in metazoans (Hebert et al. 2003). We found a higher divergence among the

365 three species $(6 \%-10 \%)$, suggesting they are reproductively isolated biological taxa. We

366 observed a smaller nucleotide divergence between $O$. bimaculoides and $O$. bimaculatus probably

367 due to their more recent divergence from a common ancestor (Hebert et al. 2003). The three

368 octopus species studied here are the main targets for small-scale fisheries in Northwest Mexico

369 and our results showed that, although their distribution ranges sometimes overlap, most of the 20

370 surveyed localities had evidence for the presence of a single species fishery, which occur in

371 different habitats. O. bimaculoides distribute in coastal habitats with low wave energy (enclosed

372 bays and coastal lagoons), although this species also lives at $20 \mathrm{~m}$ depth in rocky and forests kelp

373 habitats (Forsythe \& Hanlon 1988a; Sinn 2008). Along the west coast of the Baja California

374 peninsula exist at least 16 coastal lagoons located between Ensenada (Baja California) and Bahía

375 Magdalena (Baja California Sur) (Lankford 1977), which probably have been colonized by

376 stepping-stone events among distinct lagoons during rafting behavior (Gillespie et al. 2012).

377 Rafting has been documented for $O$. bimaculoides and $O$. bimaculatus on floating objects like

378 macroalgae (Thiel \& Gutow 2005). This paralarval dispersal mechanism could explain

379 progressive colonization events that increase the range distribution into favorable habitats. Our

380 study expanded the previously known range distribution of the three species along the west coast

381 of Baja California peninsula $\sim 800 \mathrm{~km}$ southward for $O$. bimaculoides, $\sim 400 \mathrm{~km}$ southward for $O$.

382 bimaculatus and $\sim 150 \mathrm{~km}$ northward for $O$. hubbsorum. O. bimaculatus was restricted to the

383 northern region of the Gulf of California where its distribution might be influenced by the 
384 geographic extent of a cyclonic (anti-clockwise) oceanographic gyre that drift paralarvae during

385 its summer spawning period (Castellanos-Martínez 2008; Marinone et al. 2008; Munguia-Vega

386 et al. 2014). O. bimaculatus seems to show the pattern of disjunct distribution reported for

387 several temperate species of invertebrates and fishes that are present in the northern part of the

388 west coast of the Baja California peninsula, disappear in the southern region of the Gulf of

389 California and reappear in the northern region of the Gulf of California (Bernadi et al. 2003). The

390 distribution range of $O$. hubbsorum was conceptually redefined here to include the south part of

391 the Midriff Island region in the Gulf of California (López-Uriarte et al. 2005; Moreno-Báez et al.

392 2012). Given the low number of individuals assigned to O. bimaculoides in the Gulf of

393 California, we recommend that further surveys for the species be conducted before the range of

394 the species can be confidently expanded into the Gulf of California.

The three species were sympatric along the west coast of the Baja California peninsula around the Bahia Magdalena region, while in the Gulf of California only $O$. bimaculatus and $O$.

hubbsorum were sympatric around the Midriff Island region. Both regions have been considered transition zones between temperate and tropical species (Briggs 1974; Briggs \& Bowen 2012; Brusca 2010). Given our samples were collected mainly during warm season, it is important to consider the possibility that $O$. bimaculatus and $O$. hubbsorum could be sharing the same shelters around the Midriff Islands region in different season of the year, with $O$. bimaculatus being more frequent during the cold-temperate period (October-March), while O. hubbsorum prefers warmtropical water conditions (April-September). A pattern of alternate presence of the two species

404 with different thermal preferences could explain why the octopus fishery is carried out through 405 the year in the northern Gulf of California (Moreno-Báez et al. 2012). Thus, at several localities in the northern Gulf of California both species could be the main target of the fishery during 
407 different seasons, and at least in some localities where samples in our study were assigned to $O$.

408 bimaculatus (e.g. Puerto Lobos) there have been recent field (October 2016) observations were

409 only O. hubbsorum individuals were recorded (J. F. Domínguez-Contreras and A. Munguía-

410 Vega, pers. Comm. 2016), highlighting the need for seasonal data to complement our current

411 understanding of species captured, particularly in localities near the biogeographic transition

412 zones. Individuals with mixed ancestry that could not been assigned to a single species based on

413 our criteria were found at locations were both $O$. hubbsorum and O. bimaculatus seem to be

414 present in the northern Gulf of California. These mixed individuals could be the result of either

415 low statistical power of the seven loci employed or hybrids between the two species.

416 Hybridization between octopuses has not yet been documented, however, the copulatory

417 behavior between different octopus species has been recorded, possibly due to low mate

418 availability and a short lifespan (Lutz \& Voight 1994). The likely hybridization in Northwest

419 Mexico should be further studied with a larger sample of nuclear markers.

The life history strategies of each of the three octopus species strongly influenced the

421 genetic diversity and structure among species, showing significant differences in population

422 dynamics and paralarval connectivity. O. bimaculoides without a planktonic phase (direct

423 ontogenetic development) had the smallest effective population size and the lowest genetic

424 diversity (effective alleles) and showed higher levels of relatedness within populations, more

425 structure among populations and a higher proportion of private alleles, compared to the two

426 octopus species with a planktonic paralarval stage. These observations suggest that populations

427 of $O$. bimaculoides are comparatively smaller and structured at a local geographic scale, and are

428 likely highly denso-dependent upon local recruitment. In contrast, $O$. hubbsorum and $O$.

429 bimaculatus have comparatively higher fecundity and with planktonic paralarval drift that 
430 increase their dispersal potential and opportunities for gene flow among populations (Villanueva

431 et al. 2016). These results are consistent with our hypotheses about a larger effective population

432 size that is associated to higher levels of effective alleles and lower levels of genetic relatedness

433 within populations, less genetic structure among populations and lower frequency of private

434 alleles. This implies that $O$. hubbsorum and $O$. bimaculatus might depend less on local paralarval

435 retention and more on paralarval dispersal among different populations. However, $O$.

436 bimaculatus had lower levels of genetic differentiation among populations, lower frequency of

437 private alleles that translated into an overall lower allelic richness and lower genetic relatedness

438 within populations compared to $O$. hubbsorum. In addition, effective alleles and effective

439 population size in $O$. hubbsorum were lower compared to O. bimaculatus. Although no studies

440 exist about the PPD of $O$. hubbsorum, our results are consistent with a relatively shorter PPD and

441 less potential for dispersal compared to O. bimaculatus. This agrees with a recent study

442 suggesting that for species with a planktonic phase, the duration of the planktonic phase

443 increases with mantle length at hatchling $($ O. hubbsorum $=1.2 \mathrm{~mm} \mathrm{ML} \mathrm{O.} \mathrm{bimaculatus}=2.6$

444 mm ML (Alejo-Plata \& Herrero-Alejo 2014; Ambrose 1981; Villanueva et al. 2016).

An inability to easily identify biological species hampers any effort towards their

446

447

448

449

450

451

452

management and conservation (Bickford et al. 2007). The distinct biogeography and habitat

distributions along with contrasting life history traits are expected to have strong direct effects on population parameters. These are key biological features for establishing the spatial scale, location and timing of management actions and rates of sustainable fishing for each species.

Therefore, is not advisable to continue with the current management that does not differentiate among the three species. $O$. bimaculoides with a lower effective population size, and with local populations that are mostly self-sustaining and partially isolated from other nearby populations 
453 could be highly susceptible to over exploitation, severe bottlenecks and could show long

454 recovery times if fisheries management erroneously considers all populations as a single stock

455 and ignores the biological and ecological relevance of local population dynamics. $O$.

456 bimaculoides management taking place at the level of local populations has advantages over

457 single stock management, for instance, it would be possible to assign rigorous catch quotes per

458 individual bay. The species with higher fecundity and dispersal potential (O. bimaculatus and $O$.

459 hubbsorum) may benefit from implementation of management tools that consider

460 metapopulation dynamics on a larger geographic scale and the presence of larval dispersal

461 among populations, identifying key paralarval sources and paralarval dispersal routes during the

462 PPD, spawning and hatching seasons for each species.

A critical consideration for management of the octopus fishery in the northern Gulf of

464 California is the difference in the spawning seasons between $O$. hubbsorum (spring and fall) and

O. bimaculatus (summer) and its relationship to the current patterns (direction and speed) of

466 paralarval dispersal and its impact on source-sink metapopulation dynamics. Ocean current

467 patterns in the northern Gulf of California are highly directional, or asymmetric, driven by a

468 cyclonic (anti-clockwise) gyre during spring and summer (Marinone 2012; Marinone et al. 2008)

469 when both $O$. hubbsorum and O. bimaculatus spawn. However, O. hubbsorum also spawns

470 during autumn and winter (J. F. Domínguez-Contreras and A. Munguía-Vega pers. comm. 2016)

471 when the northern Gulf of California gyre reverses to an anti-cyclonic (clockwise) direction

472 (Lavin \& Marinone 2003; Marinone 2012), effectively transforming key larval sources during

473 spring-summer into larval sinks during autumn-winter. When implementing spatial management

474 tools in systems with strong asymmetry in the direction of the currents, including marine

475 reserves, it is advised that reserves are located upstream according to the main flow to protect the 
476 sources of larvae that support multiple downstream fishing sites (Beger et al. 2014; Munguia-

477 Vega et al. 2014). These observations imply that selection of the location of marine reserves for

478 octopus in the northern Gulf of California must consider the cyclonic phase of the oceanographic

479 gyre for both octopus species and the influence of the currents during the anti-cyclonic phase for

480 O. hubbsorum. Also, temporal fishing closures based on the spawning period of a single species,

481 like the one recently implemented in the northern Gulf of California based on O. bimaculatus

482 (Opinión Técnica No. RJL/INAPESCA/DGAIPP/1065/2015; DOF. 2016, 01 junio), might be

483 only partially effective for protecting the recruitment of the other species present in the same

484 locations but with a different spawning season (O. hubbsorum, López-Uriarte et al. 2005;

485 Moreno-Báez et al. 2012). Similarly, minimum sizes of capture established based on size at

486 sexual maturity for $O$. bimaculatus might overestimate the minimum size required for $O$.

487 hubbsorum (Table 1). Also beneficial is recognizing that growth and reproductive biology in

488 octopus is augmented by higher temperatures and food availability (Forsythe \& Hanlon 1988b).

489 Our findings highlight that sustainable fisheries management will heavily depend upon

490 establishing management tools that match the geographic and habitat distribution, life history

491 and population dynamics of the biological species targeted by multi-specific fisheries.

492

493 ACKNOWLEDGEMENTS

494 We thank several fishing cooperatives, civil society organizations and fisherman that helped

495 collecting octopus samples: Sociedades Cooperativas de Producción Pesquera: de La Purísima,

496 de Bahía Magdalena y de Puerto Chale, fisherman from San Quintin and Ejido Erendira, Dra.

497 Ivonne Posada, and partners of the PANGAS project including Centro Intercultural de Estudio de 
498

499

500

501

502

503

504

505

506

507

508

509

510

511

512

513

514

515

516

517

518

519

520

521

522

523

524

525

526

527

528

529

530

531

532

533

534

535

536

Desiertos y Oceános A.C. (CEDO), Comunidad y Biodiversidad A.C, Pronatura Noroeste A.C.

and fishing cooperatives from the Northern Gulf of California. Karla Vargas and Stacy L. Sotak

helped us at various stages during microsatellite genotyping at the University of Arizona. Jaime

Gómez-Gutíerrez provided valuable feedback on earlier versions of the manuscript.

\section{REFERENCES}

Alejo-Plata M, Gómez-Márquez JL. 2015. Reproductive biology of Octopus hubbsorum (Cephalopoda: Octopodidae) from the coast of Oaxaca, Mexico. American Malacological Bulletin 33:89-100. 10.4003/006.033.0117

Alejo-Plata M, Gómez-Márquez JL, Ramos-Carrillo S, Herrera-Galindo JE. 2009. Reproducción, dieta y pesquería del pulpo Octopus hubbsorum (Mollusca: Cephalopoda) en la costa de Oaxaca, México. Revista de Biología Tropical 57:16.

Alejo-Plata M, Herrero-Alejo S. 2014. First description of eggs and paralarvae of green octopus Octopus hubbsorum (cephalopoda: Octopodidae) under laboratory conditions. American Malacological Bulletin 32:132-139. 10.4003/006.032.0101

Ambrose RF. 1981. Observations on the embryonic development and early post embryonic behavior of Octopus bimaculatus (MOLLUSCA: CEPHALOPODA). Veliger 24:8.

Ambrose RF. 1990. Octopus bimaculatus. In: Land MA, and Hochberg FG, eds. Proceedings of the workshop on the fishery and market potential of octopus in California. Washinton, DC: Smithsonian Institution, 11-22.

Amos W, Hoffman JI, Frodsham A, Zhang L, Best S, Hill AVS. 2007. Automated binning of microsatellite alleles: problems and solutions. Molecular Ecology Notes 7:10-14. 10.1111/j.14718286.2006.01560.x

Arkhipkin AI, Rodhouse PGK, Pierce GJ, Sauer W, Sakai M, Allcock L, Arguelles J, Bower JR, Castillo G, Ceriola L, Chen C-S, Chen X, Diaz-Santana M, Downey N, González AF, Granados Amores J, Green CP, Guerra A, Hendrickson LC, Ibáñez C, Ito K, Jereb P, Kato Y, Katugin ON, Kawano M, Kidokoro H, Kulik VV, Laptikhovsky VV, Lipinski MR, Liu B, Mariátegui L, Marin W, Medina A, Miki K, Miyahara K, Moltschaniwskyj N, Moustahfid H, Nabhitabhata J, Nanjo N, Nigmatullin CM, Ohtani T, Pecl G, Perez JAA, Piatkowski U, Saikliang P, Salinas-Zavala CA, Steer M, Tian Y, Ueta Y, Vijai D, Wakabayashi T, Yamaguchi T, Yamashiro C, Yamashita N, Zeidberg LD. 2015. World Squid Fisheries. Reviews in Fisheries Science \& Aquaculture 23:92-252. 10.1080/23308249.2015.1026226

Beger M, Selkoe KA, Treml EA, Barber PH, von der Heyden S, Crandall ED, Toonen RJ, Riginos C. 2014. Evolving coral reef conservation with genetic information. Bulletin of Marine Science 90:159185. 10.5343/bms.2012.1106

Bernadi G, Findley L, Rocha-Olivares A. 2003. Vicariance and dispersal across Baja California in disjunct marine fish populations. Evolution 7:1599-1609.

Berry SS. 1953. Preliminary diagnoses of six west american species of octopus. Leaflets in Malacology 1:51-58. 
537

Bickford D, Lohman DJ, Sodhi NS, Ng PK, Meier R, Winker K, Ingram KK, Das I. 2007. Cryptic species as a window on diversity and conservation. Trends in Ecology \& Evolution 22:148-155. 10.1016/j.tree.2006.11.004

Boyle PR, vonBoletzky S. 1996. Cephalopod populations: Definition and dynamics. Philosophical Transactions of the Royal Society of London Series B-Biological Sciences 351:985-1002. DOI 10.1098/rstb.1996.0089

Briggs JC. 1974. Marine zoogeography. USA: McGraw-Hill, Inc.

Briggs JC, Bowen BW. 2012. A realignment of marine biogeographic provinces with particular reference to fish distributions. Journal of Biogeography 39:12-30. 10.1111/j.1365-2699.2011.02613.x

Brusca RC. 1980. Common intertidal invertebrates of the Gulf of California. Tucson, Arizona, USA: The University of Arizona Press.

Brusca RC. 2010. The Gulf of California: biodiversity and conservation. USA: The University of Arizona Press.

Burgess SC, Nickols KJ, Griesemer CD, Barnett LAK, Dedrick AG, Satterthwaite EV, Yamane L, Morgan SG, White JW, Botsford LW. 2014. Beyond connectivity: how empirical methods can quantify population persistence to improve marine protected area design. Ecological Applications 24:257-270.

Byers JE, Pringle JM. 2006. Going against the flow: retention, range limits and invasions in advective environments. Marine Ecology Progress Series 313:27-41.

Cardenas-Robles ED. 2013. Fecundidad en el pulpo Octopus bimaculatus Verrill, 1883 (CEPHALOPODA:OCTOPODIDADE)en Bahía de Los Ángeles, Baja California, México. Bachelor. Universidad Autonoma de Baja California Sur.

Castellanos-Martínez S. 2008. Reproducción del pulpo Octopus bimaculatus Verrill, 1883 en Bahía de los Ángeles, Baja California, México. Master thesis. Instituto politécnico Nacional.

Chapuis MP, Estoup A. 2007. Microsatellite null alleles and estimation of population differentiation. Molecular Biology and Evolution 24:621-631. 10.1093/molbev/ms/191

Charlesworth B. 2009. Effective population size and patterns of molecular evolution and variation. Nature Review Genetics 10:195-205. 10.1038/nrg2526

Christie MR, Johnson DW, Stallings CD, Hixon MA. 2010. Self-recruitment and sweepstakes reproduction amid extensive gene flow in a coral-reef fish. Molecular Ecology 19:1042-1057. 10.1111/j.1365294X.2010.04524.x

CONAPESCA. 2014. Anuario estadístico de acuacultura y pesca 2013. México: Comisión Nacional de Acuacultura y Pesca.

Darriba D, Taboada GL, Doallo R, Posada D. 2012. jModelTest 2: more models, new heuristics and parallel computing. Nature Methods 9:772. 10.1038/nmeth.2109

Do C, Waples RS, Peel D, Macbeth GM, Tillett BJ, Ovenden JR. 2014. NeEstimator v2: re-implementation of software for the estimation of contemporary effective population size ( $\mathrm{Ne}$ ) from genetic data. Molecular Ecology Resources 14:209-214. 10.1111/1755-0998.12157

DOF. 2016, 01 junio. Acuerdo por el que se establece la veda temporal y tallas mínimas de captura para la pesca de las especies de pulpo en Bahía de los Ángeles, Baja California. In: SAGARPA, editor. Mexico.

Domínguez-Contreras JF. 2011. Reproducción del pulpo Octopus hubbsorum Berry, 1953 en Bahía Magdalena, B.C.S, México. Master. UNAM.

Domínguez-Contreras JF, Ceballos-Vázquez BP, Hochberg FG, Arellano-Martínez M. 2013. A new record in a well-established population of Octopus hubbsorum (Cephalopoda: Octopodidae) expands its known geographic distribution range and maximum size. American Malacological Bulletin 31:9599. 10.4003/006.031.0122 
584

585

586

587

588

589

590

591

592

593

594

595

596

597

598

599

600

601

602

603

604

605

606

607

608

609

610

611

612

613

614

615

616

617

618

619

620

621

622

623

624

625

626

627

628

629

630

631

Domínguez-Contreras JF, Munguía-Vega A, Ceballos-Vázquez BP, Arellano-Martínez M, Culver M. 2014. Characterization of microsatellite loci from two-spotted octopus Octopus bimaculatus Verrill 1883 from pyrosequencing reads. Conservation Genetics Resources 6:465-468. 10.1007/s12686013-0128-x

Doubleday ZA, Prowse TAA, Arkhipkin A, Pierce GJ, Semmens J, Steer M, Leporati SC, Lourenço S, Quetglas A, Sauer W, Gillanders BM. 2016. Global proliferation of cephalopods. Current Biology 26:R406-R407. 10.1016/j.cub.2016.04.002

Ellegren H, Galtier N. 2016. Determinants of genetic diversity. Nature Review Genetics 17:422-433. 10.1038/nrg.2016.58

Evanno G, Regnaut S, Goudet J. 2005. Detecting the number of clusters of individuals using the software STRUCTURE: a simulation study. Molecular Ecology 14:2611-2620. 10.1111/j.1365294X.2005.02553.x

FAO. 2015. The state of world fisheries and aquaculture, Food and Agriculture. Organization of the United Nations. Rome, Italy.

Finkbeiner EM. 2015. The role of diversification in dynamic small-scale fisheries: Lessons from Baja California Sur, Mexico. Global Environmental Change 32:139-152. 10.1016/j.gloenvcha.2015.03.009

Finkbeiner EM, Basurto X. 2015. Re-defining co-management to facilitate small-scale fisheries reform: An illustration from northwest Mexico. Marine Policy 51:433-441. 10.1016/j.marpol.2014.10.010

Folmer O, Black M, Hoeh W, Lutz R, Vrijenhoek R. 1994. DNA primers for amplification of mitochondrial cytochrome c oxidase subunit I from diverse metazoan invertebrates. Molecular Marine Biology and Biotechnology 3:294-299.

Forsythe JW, Hanlon RT. 1988a. Behavior, body patterning and reproductive biology of Octopus bimaculoides from california. Malacologia 29:41-55.

Forsythe JW, Hanlon RT. 1988b. Effect of Temperature on Laboratory Growth, Reproduction and LifeSpan of Octopus bimaculoides. Marine Biology 98:369-379. Doi 10.1007/Bf00391113

Garcia-Vazquez E, Machado-Schiaffino G, Campo D, Juanes F. 2012. Species misidentification in mixed hake fisheries may lead to overexploitation and population bottlenecks. Fisheries Research 114:52-55. 10.1016/j.fishres.2011.05.012

Gillespie RG, Baldwin BG, Waters JM, Fraser Cl, Nikula R, Roderick GK. 2012. Long-distance dispersal: a framework for hypothesis testing. Trends in Ecology \& Evolution 27:47-56. 10.1016/j.tree.2011.08.009

González-Meléndez M. 2012. Análisis cualitativo sobre el método de pesca para el pulpo de laguna Guerrero Negro, B. C. S., y sus implicaciones sociales Bachelor. UABCS.

Gotshall DW. 1998. Marine Animals of Baja California: A guide to the common fishes and invertebrates Baja California to Panama. Monterey, California.

Guindon S, Gascuel O. 2003. A simple, fast, and accurate algorithm to estimate large phylogenies by maximum likelihood. Systematic Biology 52:696-704. 10.1080/10635150390235520

Hanlon RT. 1988. Behavioral and body patterning characters useful in taxonomy and field identification of cephalopods. Malacologia 29:247-264.

Hebert PD, Cywinska A, Ball SL, deWaard JR. 2003. Biological identifications through DNA barcodes. Proceedings of the Royal Society B: Biological Sciences 270:313-321. 10.1098/rspb.2002.2218

Hochberg FG, Fields WG. 1980. Cephalopoda: the squids and octopuses. In: Morris MH, Abbott DP, and Haderlie EC, eds. Intertidal invertebrates of California. Stanford, California.: Stanford University. Press, 429-444.

Hunsicker ME, Essington TE, Watson R, Sumaila UR. 2010. The contribution of cephalopods to global marine fisheries: can we have our squid and eat them too? Fish and Fisheries 11:421-438. 10.1111/j.1467-2979.2010.00369.x 
632

633

634

635

636

637

638

639

640

641

642

643

644

645

646

647

648

649

650

651

652

653

654

655

656

657

658

659

660

661

662

663

664

665

666

667

668

669

670

671

672

673

674

675

676

677

678

Iglesias J, Sánchez FJ, Bersano JGF, Carrasco JF, Dhont J, Fuentes L, Linares F, Muñoz JL, Okumura S, Roo J, van der Meeren T, Vidal EAG, Villanueva R. 2007. Rearing of Octopus vulgaris paralarvae: Present status, bottlenecks and trends. Aquaculture 266:1-15. 10.1016/j.aquaculture.2007.02.019

Jurado-Molina J. 2010. A Bayesian framework with implementation error to improve the management of the red octopus (Octopus maya) fishery off the Yucatán Peninsula. Ciencias Marinas 36:1-14.

Kalinowski ST. 2005. HP-rare: a computer program for performing rarefaction on measures of allelic diversity. Molecular Ecology Notes 5.

Kimura M. 1983. The Neutral Theory of Molecular Evolution Cambridge University Press.

Kopelman NM, Mayzel J, Jakobsson M, Rosenberg NA, Mayrose I. 2015. Clumpak: a program for identifying clustering modes and packaging population structure inferences across K. Molecular Ecology Resources. 10.1111/1755-0998.12387

Lankford RR. 1977. COASTAL LAGOONS OF MEXICO THEIR ORIGIN AND CLASSIFICATION. In: Wiley M, ed. Estuarine Processes: Academic Press, 182-215.

Lavin MF, Marinone SG. 2003. An overview of the physical oceanography of the gulf of California. Nonlinear Processes in Geophysical Fluid Dynamics, 173-204.

López-Rocha JA, Arellano-Martínez M, Ceballos-Vázquez BP, Velázquez-Abunader I, Castellanos-Martínez S, Torreblanca-Ramírez E. 2012. Use of length-frequency analysis for growth estimation of the California two-spotted octopus Octopus bimaculatus Verrill 1883 of the Gulf of California. Journal of Shellfish Research 31:1173-1181. 10.2983/035.031.0428

López-Uriarte E, Rios-Jara E. 2009. Reproductive biology of Octopus hubbsorum (Mollusca:Cephalopoda) along the central mexican Pacific coast. Bulletin of Marine Science 84:13.

López-Uriarte E, Ríos-Jara E, Pérez-Peña M. 2005. Range extension for Octopus hubbsorum (Cephalopoda: Octopodidae) in the Mexican Pacific. Bulletin of Marine Science 77:9.

Lutz RA, Voight JR. 1994. Close Encounter in the Deep. Nature 371:563-563. Doi 10.1038/371563a0

Marinone SG. 2012. Seasonal surface connectivity in the Gulf of California. Estuarine Coastal and Shelf Science 100:133-141. 10.1016/j.ecss.2012.01.003

Marinone SG, Ulloa MJ, Pares-Sierra A, Lavin MF, Cudney-Bueno R. 2008. Connectivity in the northern Gulf of California from particle tracking in a three-dimensional numerical model. Journal of Marine Systems 71:149-158. 10.1076/j.jmarsys.2007.06.005

Marko PB, Lee SC, Rice AM, Gramling JM, Fitzhenry TM, McAlister JS, Harper GR, Moran AL. 2004. Fisheries: mislabelling of a depleted reef fish. Nature 430:309-310. 10.1038/430309b

Moreno-Báez M, Cudney-Bueno R, Orr BJ, Shaw WW, Pfister T, Torre-Cosio J, Loaiza R, Rojo M. 2012. Integrating the spatial and temporal dimensions of fishing activities for management in the northern Gulf of California, mexico. Ocean \& Coastal Management 55:111-127. 10.1016/j.ocecoaman.2011.10.001

Munguia-Vega A, Jackson A, Marinone SG, Erisman B, Moreno-Baez M, Giron-Nava A, Pfister T, AburtoOropeza O, Torre J. 2014. Asymmetric connectivity of spawning aggregations of a commercially important marine fish using a multidisciplinary approach. PeerJ 2:e511. 10.7717/peerj.511

Munguía-Vega A, Sáenz-Arroyo A, Greenley AP, Espinoza-Montes JA, Palumbi SR, Rossetto M, Micheli F. 2015. Marine reserves help preserve genetic diversity after impacts derived from climate variability: Lessons from the pink abalone in Baja California. Global Ecology and Conservation 4:264-276. 10.1016/j.gecco.2015.07.005

Norman MD, Hochberg FG. 2005. The current state of octopus taxonomy. Phuket Marine Biological Center Research Bulletin 66:28.

Palumbi SR, Martin AP, Romano SL, McMillan WO, Stacey L, Grabowski G. 1991. The Simple Fool's Guide to PCR. University of Hawaii, Honolulu.: Department of Zoology Special Publication. 
679

680

681

682

683

684

685

686

687

688

689

690

691

692

693

694

695

696

697

698

699

700

701

702

703

704

705

706

707

708

709

710

711

712

713

714

715

716

717

718

719

720

721

722

723

724

725
Pauly D, Christensen V, Guenette S, Pitcher TJ, Sumaila UR, Walters CJ, Watson R, Zeller D. 2002. Towards sustainability in world fisheries. Nature 418:689-695. 10.1038/nature01017

Peakall R, Smouse PE. 2012. GenAlEx 6.5: genetic analysis in Excel. Population genetic software for teaching and research--an update. Bioinformatics 28:2537-2539. 10.1093/bioinformatics/bts460

Pickford GE, MacConnaughey BH. 1949. The Octopus bimaculatus problem: a study in sibling species. Yale University: Peabody Museum of Natural History.

Pritchard JK, Stephens M, Donnelly P. 2000. Inference of population structure using multilocus genotype data. Genetics 155:945-959.

Queller DC, Goodnight KF. 1989. Estimating relatedness using genetic-markers. Evolution 43:258-275. Doi 10.2307/2409206

Raymond M, Rousset F. 1995. GENEPOP (Version 1.2): Population genetics software for exact tests and ecumenicism. Journal of Heredity 86:248-249.

Riginos C, Liggins L. 2013. Seascape Genetics: Populations, Individuals, and Genes Marooned and Adrift. Geography Compass 7:197-216. 10.1111/gec3.12032

Romiguier J, Gayral P, Ballenghien M, Bernard A, Cahais V, Chenuil A, Chiari Y, Dernat R, Duret L, Faivre N, Loire E, Lourenco JM, Nabholz B, Roux C, Tsagkogeorga G, Weber AA, Weinert LA, Belkhir K, Bierne N, Glemin S, Galtier N. 2014. Comparative population genomics in animals uncovers the determinants of genetic diversity. Nature 515:261-263. 10.1038/nature13685

Roper CFE, Sweeney MJ, Hochberg FG. 1995. Cefalópodos. In: Fischer W, Krup F, Schneider W, Sommer C, E CK, and Niem VH, eds. Guía FAO para la identificación de especies para los fines de la pesca Pacífico Centro-Oriental. Roma: FAO, 305-353.

Sala E, Aburto-Oropeza O, Reza M, Paredes G, López-Lemus LG. 2004. Fishing Down Coastal Food Webs in the Gulf of California. Fisheries 29:19-25. 10.1577/1548-8446(2004)29[19:fdcfwi]2.0.co;2

Selkoe KA, Gaggiotti OE, Bowen BW, Toonen RJ. 2014. Emergent patterns of population genetic structure for a coral reef community. Molecular Ecology 23:3064-3079. 10.1111/mec.12804

Selkoe KA, Toonen RJ. 2011. Marine connectivity: a new look at pelagic larval duration and genetic metrics of dispersal. Mar Ecol Prog Ser 436:291-305. 10.3354/meps09238

Shanks AL. 2009. Pelagic Larval Duration and Dispersal Distance Revisited. Biological Bulletin 216:373385.

Sinn DL. 2008. Patterns of activity cycles in juvenile California two-spot octopuses (Octopus bimaculoides). American Malacological Bulletin 24:65-69. 10.4003/0740-2783-24.1.65

Tamura K, Stecher G, Peterson D, Filipski A, Kumar S. 2013. MEGA6: Molecular Evolutionary Genetics Analysis version 6.0. Molecular Biology and Evolution 30:2725-2729. 10.1093/molbev/mst197

Thiel M, Gutow L. 2005. The ecology of rafting in the marine environment. II. The rafting organisms and community. Oceanography and Marine Biology - an Annual Review, Vol 43 43:279-418. Book_Doi 10.1201/9781420037449

Van Oosterhout C, Hutchinson WF, Wills DPM, Shipley P. 2004. micro-checker: software for identifying and correcting genotyping errors in microsatellite data. Molecular Ecology Notes 4:535-538. 10.1111/j.1471-8286.2004.00684.x

Villanueva R, Vidal EA, Fernandez-Alvarez FA, Nabhitabhata J. 2016. Early Mode of Life and Hatchling Size in Cephalopod Molluscs: Influence on the Species Distributional Ranges. PLoS One 11:e0165334. 10.1371/journal.pone.0165334

Villegas EJA, Ceballos-Vázquez BP, Markaida U, Abitia-Cárdenas A, Medina-López MA, Arellano-Martínez M. 2014. Diet of Octopus bimaculatus Verril, 1883 (Cephalopoda: Octopodidae) in Bahía De Los Ángeles, Gulf of California. Journal of Shellfish Research 33:305-314. 10.2983/035.033.0129

Watson R, Pauly D. 2001. Systematic distortion in world fisheries catch trends. Nature 414:534-536. 


\section{Table 1 (on next page)}

Life history

Life history of three species of octopus from Northwest Mexico. BCP = Baja California Peninsula, $\mathrm{ML}=$ Mantle Length. 


\begin{tabular}{|c|c|c|c|c|}
\hline Life history & O. bimaculoides & O. hubbsorum & O. bimaculatus & References \\
\hline $\begin{array}{l}\text { Geographic } \\
\text { distribution }\end{array}$ & $\begin{array}{c}\text { From CA, USA to Bahia } \\
\text { San Quintin in BC, } \\
\text { Mexico. }\end{array}$ & $\begin{array}{l}\text { From Bahia Magdalena, } \\
\text { BCS to Oaxaca, including } \\
\text { the Gulf of California. }\end{array}$ & $\begin{array}{l}\text { From CA, USA to Bahia } \\
\text { Vizcaino BCS, including the } \\
\text { Gulf of California }\end{array}$ & $(2,3,4$ and 10$)$ \\
\hline $\begin{array}{l}\text { Reproductive } \\
\text { period }\end{array}$ & $\begin{array}{l}\text { Santa Barbara, CA, } \\
\text { USA (Dec-May) } \\
\text { San Quintin, BCP, } \\
\text { Mexico (Oct-Jan) }\end{array}$ & $\begin{array}{l}\text { Pacific coast of BCP } \\
\quad \text { (May-Oct) } \\
\text { Gulf of California } \\
\text { (Mar, Sep-Dec) }\end{array}$ & $\begin{array}{l}\text { Pacific coast of BCP } \\
\text { (Jan-Jun) } \\
\text { Gulf of California } \\
\text { (Jun-Sep) }\end{array}$ & $\begin{array}{c}(1,2,3,5, \text { and } \\
8)\end{array}$ \\
\hline *Fecundity & $\begin{array}{c}\text { Eggs laid in festoons } \\
137-780\end{array}$ & $\begin{array}{c}\text { Clutch eggs } \\
105,000-144,000 \\
\\
\text { Ripe ovarian eggs } \\
240,050 \\
\text { (range } 22,447-545,444 \text { ) }\end{array}$ & $\begin{array}{c}\text { Clutch eggs } \\
>20,000 \\
\text { Ripe ovarian eggs } \\
91,407 \pm 75,361 \text { SD (range } \\
11,618-372,269)\end{array}$ & $\begin{array}{l}(1,2,6,9,11 \\
\text { and } 12)\end{array}$ \\
\hline $\begin{array}{l}\text { *Egg size (length) } \\
\text { and ripe ovarian } \\
\text { eggs size }\end{array}$ & $\begin{array}{c}10-12 \mathrm{~mm} \\
\text { (range } 9.5-16 \mathrm{~mm})\end{array}$ & $\begin{array}{l}1.66 \pm 0.74 \mathrm{~mm} \\
\text { Ripe ovarian eggs } 2.07 \mathrm{~mm} \\
(\text { range } 0.7-3.7 \mathrm{~mm})\end{array}$ & $\begin{array}{l}\quad 4-7 \mathrm{~mm} \\
\text { Ripe ovarian eggs } \\
\text { (range } 1.8-4 \mathrm{~mm} \text { ) }\end{array}$ & $\begin{array}{l}(1,2,3,9,11 \\
\quad \text { and } 12)\end{array}$ \\
\hline $\begin{array}{c}\text { Planktonic larval } \\
\text { duration } \\
\text { (paralarvae) }\end{array}$ & $\begin{array}{c}\text { absent, direct } \\
\text { development to } \\
\text { juvenile, benthic } \\
\text { hatchlings }\end{array}$ & $\begin{array}{l}\text { Present but the time is } \\
\text { uncertain (Probably } \sim 60 \\
\text { days) }\end{array}$ & $\begin{array}{c}2-3 \text { months (60 to } 90 \\
\text { days) }\end{array}$ & $(1,2,3$, and 11$)$ \\
\hline
\end{tabular}




\begin{tabular}{|c|c|c|c|c|}
\hline $\begin{array}{l}\text { Size at sexual } \\
\text { maturity }\end{array}$ & $\begin{array}{c}55 \mathrm{~mm} \text { (ML) males } \\
110 \mathrm{~mm} \text { (ML) females }\end{array}$ & $\begin{array}{c}70 \mathrm{~mm}(\mathrm{ML}) \text { males } \\
119.7 \mathrm{~mm}(\mathrm{ML}) \text { females }\end{array}$ & $\begin{array}{c}124.5 \mathrm{~mm}(\mathrm{ML}) \text { males } \\
147.0 \mathrm{~mm}(\mathrm{ML}) \text { females }\end{array}$ & $(2,6,8$, and 12$)$ \\
\hline Lifespan (years) & Short $(1.0-1.5)$ & Short (1.5) & Short $(1.5-2.0)$ & $(2,3$, and 6$)$ \\
\hline
\end{tabular}

* = considering average, min and max reported value. (1) Ambrose (1981), (2) Forsythe \& Hanlon (1988), (3) Ambrose (1990), (4) López-Uriarte et al. (2005), (5) Castellanos-Martínez (2008), (6) López-Uriarte \& Rios-Jara (2009), (8) Domínguez-Contreras (2011), (9) Cardenas-Robles (2013), (10) Domínguez-Contreras et al. (2013), (11) Alejo-Plata \& Herrero-Alejo (2014) and (12) Alejo-Plata \& Gómez-Márquez (2015). 


\section{Table 2 (on next page)}

\section{Hypotheses}

Hypotheses regarding levels of genetic diversity and structure based on the life history of three species of octopus from Northwest Mexico. 


\begin{tabular}{|c|c|c|c|c|}
\hline Hypotheses & O. bimaculoides & O. hubbsorum & O. bimaculatus & References \\
\hline $\begin{array}{c}\text { Effective } \\
\text { population size } \\
\left(N_{e}\right)\end{array}$ & Small & Medium & Large & (1 and 2) \\
\hline $\begin{array}{c}\text { Genetic diversity } \\
\text { (allelic richness) } \\
\quad\left(\mathrm{N}_{\mathrm{E}}, \mathrm{R}_{\mathrm{A}}\right)\end{array}$ & Low & Medium & High & (1 and 2) \\
\hline $\begin{array}{c}\text { Diversity of } \\
\text { private alleles } \\
\left(\mathrm{R}_{\mathrm{PA}}\right)\end{array}$ & High & Medium & Low & (3 and 4) \\
\hline $\begin{array}{l}\text { Genetic } \\
\text { Structure } \\
\quad\left(F_{S T}\right)\end{array}$ & High & Medium & Low & $(5,6$, and 7$)$ \\
\hline $\begin{array}{l}\text { Genetic } \\
\text { relatedness } \\
\text { (R) }\end{array}$ & High & Medium & Low & (8 and 9) \\
\hline
\end{tabular}

(1) Romiguier et al. (2014), (2) Ellegren \& Galtier (2016), (3) Beger et al. (2014), (4) Munguía-Vega et al. (2015), (5) Selkoe \& Toonen (2011), (6) Riginos \& Liggins (2013), (7) Selkoe et al. (2014), (8) Christie et al. (2010), (9) Burgess et al. (2014) 


\section{Table 3(on next page)}

Nucleotide divergence of both: 16s rDNA gene and COI gene

Nucleotide divergence between species of octopus identified through the analysis of both the 16s rRNA gene (below the diagonal) and COI gene (above the diagonal). Standard error estimates are shown in parentheses. 


\begin{tabular}{lccc}
\hline & O. bimaculoides & O. bimaculatus & O. hubbsorum \\
\hline O. bimaculoides & - & $0.0632( \pm 0.0104)$ & $0.1005( \pm 0.0142)$ \\
O. bimaculatus & $0.0328( \pm 0.0079)$ & - & $0.1042( \pm 0.0139)$ \\
O. hubbsorum & $0.0629( \pm 0.0113)$ & $0.0708( \pm 0.123)$ & - \\
\hline
\end{tabular}




\section{Table 4 (on next page)}

Genetic variation within populations of three species of octopus

Sample Size $(N)$, Mean \pm Standard Error $(S E)$ of the number of alleles $\left(N_{A}\right)$, effective alleles

$\left(N_{E}\right)$, and observed $\left(H_{0}\right)$, expected $\left(H_{E}\right)$ heterozygosities, alellic richness $\left(R_{A}\right)$ and private allelic richness $\left(R_{P A}\right)$. 


\begin{tabular}{|c|c|c|c|c|c|c|c|c|}
\hline Species & Population & $\mathbf{N}$ & $\mathbf{N}_{\mathrm{A}}$ & $\mathbf{N}_{\mathrm{E}}$ & $\mathrm{H}_{\mathrm{O}}$ & $\mathbf{H}_{E}$ & $\mathbf{R}_{\mathbf{A}}$ & $\mathbf{R}_{\mathrm{PA}}$ \\
\hline Octopus & Ejido Erendira & 13 & $5.00 \pm 0.93$ & $3.08 \pm 0.52$ & $0.78 \pm 0.08$ & $0.61 \pm 0.07$ & $3.97 \pm 0.64$ & $1.06 \pm 0.27$ \\
\hline \multirow[t]{3}{*}{ bimaculoides } & San Quintín & 9 & $6.14 \pm 1.49$ & $4.44 \pm 1.18$ & $0.52 \pm 0.12$ & $0.62 \pm 0.11$ & $5.46 \pm 1.23$ & $3.28 \pm 1.54$ \\
\hline & Bahía Magdalena & 9 & $4.29 \pm 0.71$ & $3.34 \pm 0.62$ & $0.91 \pm 0.05$ & $0.65 \pm 0.05$ & $4.08 \pm 0.65$ & $2.33 \pm 0.63$ \\
\hline & Mean \pm SE & & $5.00 \pm 0.61$ & $3.62 \pm 0.47$ & $0.74 \pm 0.06$ & $0.63 \pm 0.04$ & $4.50 \pm 0.48$ & $1.60 \pm 0.48$ \\
\hline Octopus & Puerto Libertad & 9 & $5.00 \pm 1.31$ & $4.09 \pm 1.07$ & $0.65 \pm 0.12$ & $0.59 \pm 0.12$ & $4.28 \pm 0.98$ & $0.53 \pm 0.31$ \\
\hline \multirow[t]{6}{*}{ hubbsorum } & Isla San Lorenzo & 19 & $5.71 \pm 1.11$ & $3.87 \pm 0.83$ & $0.62 \pm 0.14$ & $0.61 \pm 0.10$ & $4.43 \pm 0.79$ & $1.59 \pm 0.56$ \\
\hline & Isla Tiburón & 24 & $7.57 \pm 2.07$ & $5.15 \pm 1.53$ & $0.58 \pm 0.15$ & $0.61 \pm 0.13$ & $4.46 \pm 0.96$ & $0.51 \pm 0.24$ \\
\hline & Bahía Kino & 31 & $8.86 \pm 2.22$ & $5.88 \pm 1.50$ & $0.52 \pm 0.12$ & $0.67 \pm 0.10$ & $4.91 \pm 0.91$ & $0.49 \pm 0.18$ \\
\hline & Santa Rosalía & 8 & $9.86 \pm 2.84$ & $6.31 \pm 1.79$ & $0.70 \pm 0.14$ & $0.66 \pm 0.13$ & $4.78 \pm 1.00$ & $0.33 \pm 0.24$ \\
\hline & El Conejo & 8 & $6.57 \pm 1.51$ & $4.82 \pm 1.14$ & $0.75 \pm 0.12$ & $0.66 \pm 0.11$ & $5.00 \pm 0.99$ & $0.69 \pm 0.21$ \\
\hline & Mean \pm SE & & $7.26 \pm 0.79$ & $5.02 \pm 0.53$ & $0.64 \pm 0.05$ & $0.64 \pm 0.04$ & $4.54 \pm 0.12$ & $0.69 \pm 0.19$ \\
\hline Octopus & La Bocana & 4 & $5.29 \pm 0.47$ & $4.36 \pm 0.54$ & $0.93 \pm 0.07$ & $0.75 \pm 0.03$ & $4.35 \pm 0.34$ & $0.15 \pm 0.04$ \\
\hline \multirow[t]{9}{*}{ bimaculatus } & Las Barrancas & 3 & $3.71 \pm 0.52$ & $3.23 \pm 0.45$ & $0.81 \pm 0.14$ & $0.61 \pm 0.10$ & $3.71 \pm 0.52$ & $0.14 \pm 0.06$ \\
\hline & Malarrimo & 31 & $11.43 \pm 0.81$ & $6.05 \pm 0.82$ & $0.80 \pm 0.08$ & $0.79 \pm 0.06$ & $4.08 \pm 0.30$ & $0.40 \pm 0.15$ \\
\hline & Puerto Peñasco & 21 & $10.29 \pm 1.02$ & $6.67 \pm 1.04$ & $0.87 \pm 0.07$ & $0.79 \pm 0.07$ & $4.21 \pm 0.36$ & $0.33 \pm 0.08$ \\
\hline & San Luis Gonzaga & 8 & $6.71 \pm 1.02$ & $5.20 \pm 0.76$ & $0.79 \pm 0.14$ & $0.71 \pm 0.12$ & $4.02 \pm 0.51$ & $0.12 \pm 0.06$ \\
\hline & Puerto Refugio & 12 & $8.00 \pm 1.02$ & $5.65 \pm 0.81$ & $0.68 \pm 0.11$ & $0.76 \pm 0.08$ & $4.07 \pm 0.38$ & $0.33 \pm 0.11$ \\
\hline & Isla Smith & 25 & $11.14 \pm 1.24$ & $6.76 \pm 0.89$ & $0.84 \pm 0.06$ & $0.81 \pm 0.06$ & $4.25 \pm 0.32$ & $0.40 \pm 0.09$ \\
\hline & B.de Los Ángeles & 14 & $9.57 \pm 0.75$ & $6.20 \pm 0.89$ & $0.68 \pm 0.10$ & $0.78 \pm 0.07$ & $4.23 \pm 0.35$ & $0.24 \pm 0.04$ \\
\hline & Puerto Lobos & 20 & $10.14 \pm 0.86$ & $6.64 \pm 0.79$ & $0.80 \pm 0.08$ & $0.82 \pm 0.04$ & $4.34 \pm 0.23$ & $0.44 \pm 0.17$ \\
\hline & Mean \pm SE & & $8.48 \pm 0.43$ & $5.64 \pm 0.29$ & $0.80 \pm 0.03$ & $0.76 \pm 0.02$ & $4.14 \pm 0.07$ & $0.28 \pm 0.04$ \\
\hline
\end{tabular}




\section{Table 5 (on next page)}

Contemporary effective population size

Average and $95 \%$ confidence intervals for the contemporary effective population size $\left(N_{e}\right)$ for three species of octopus. Locations were pooled according to the results of the genetic assignment of species (Fig. 2). $N_{e}$ was estimated with two methods, including linkage disequilibrium (LD; lowest allele frequency used 0.05 and 0.02 respectively) and Molecular coancestry $\left(M_{c}\right)$. 


\begin{tabular}{lccc}
\hline & LDNE $\mathbf{0 . 0 5}$ & LDNE $\mathbf{0 . 0 2}$ & $\mathbf{M}_{\mathbf{C}}$ \\
\hline O. bimaculoides & $9.7(6.4-13.9)$ & $17.9(13.6-24.0)$ & $9.9(3.6-19.2)$ \\
O. bimaculatus & $190.2(129.2-324.2)$ & $252.7(182.8-388.8)$ & $\infty(\infty-\infty)$ \\
O. hubbsorum & $104.8(69.9-181.3)$ & $131.4(95.7-197.1)$ & $28.1(6.8-64.3)$ \\
\hline
\end{tabular}




\section{Table 6 (on next page)}

Analysis of molecular variance (AMOVA) from microsatellite data within three species of octopus from Northwest México. 


\begin{tabular}{|c|c|c|c|c|c|c|c|}
\hline Species & Source of Variation & Variance & $d f$ & $\begin{array}{l}\text { Sum of } \\
\text { squares }\end{array}$ & $\begin{array}{l}\text { Means of } \\
\text { squares }\end{array}$ & $\begin{array}{l}\text { Estimated } \\
\text { Variance }\end{array}$ & $\begin{array}{c}P \\
\text { Value }\end{array}$ \\
\hline Octopus & Among Populations $\left(\mathrm{F}_{\mathrm{ST}}\right)$ & $19 \%$ & 2 & 28.808 & 14.404 & 0.610 & 0.000 \\
\hline \multirow[t]{3}{*}{ bimaculoides } & Among Indiv $\left(F_{\mid S}\right)$ & $0 \%$ & 28 & 56.338 & 2.012 & 0.000 & 1.000 \\
\hline & Within Indiv $\left(F_{T T}\right)$ & $81 \%$ & 31 & 80.000 & 2.581 & 2.581 & 0.005 \\
\hline & Total & $100 \%$ & 61 & 165.145 & & 3.190 & \\
\hline Octopus & Among Populations $\left(\mathrm{F}_{\mathrm{ST}}\right)$ & $16 \%$ & 5 & 87.004 & 17.401 & 0.471 & 0.000 \\
\hline \multirow[t]{3}{*}{ hubbsorum } & Among Indiv $\left(F_{I S}\right)$ & $11 \%$ & 93 & 256.834 & 2.762 & 0.308 & 0.000 \\
\hline & Within Indiv $\left(F_{I T}\right)$ & $73 \%$ & 99 & 212.500 & 2.146 & 2.146 & 0.000 \\
\hline & Total & $100 \%$ & 197 & 556.338 & & 2.925 & \\
\hline Octopus & Among Populations $\left(\mathrm{F}_{\mathrm{ST}}\right)$ & $9 \%$ & 8 & 92.321 & 11.540 & 0.293 & 0.000 \\
\hline \multirow[t]{3}{*}{ bimaculatus } & Among Indiv $\left(F_{\mid S}\right)$ & $3 \%$ & 129 & 380.349 & 2.948 & 0.094 & 0.003 \\
\hline & Within Indiv $\left(F_{I T}\right)$ & $88 \%$ & 138 & 381.000 & 2.761 & 2.761 & 0.000 \\
\hline & Total & $100 \%$ & 275 & 853.670 & & 3.148 & \\
\hline
\end{tabular}




\section{Figure 1 (on next page)}

Study area

Locations of 20 octopus populations sampled from Northwest Mexico. B.C = Baja California.

B. C. S = Baja California Sur. NGC = Northern Gulf of California. The blue stars represent main fishing localities, and the red circle represents the Midriff Island region. 


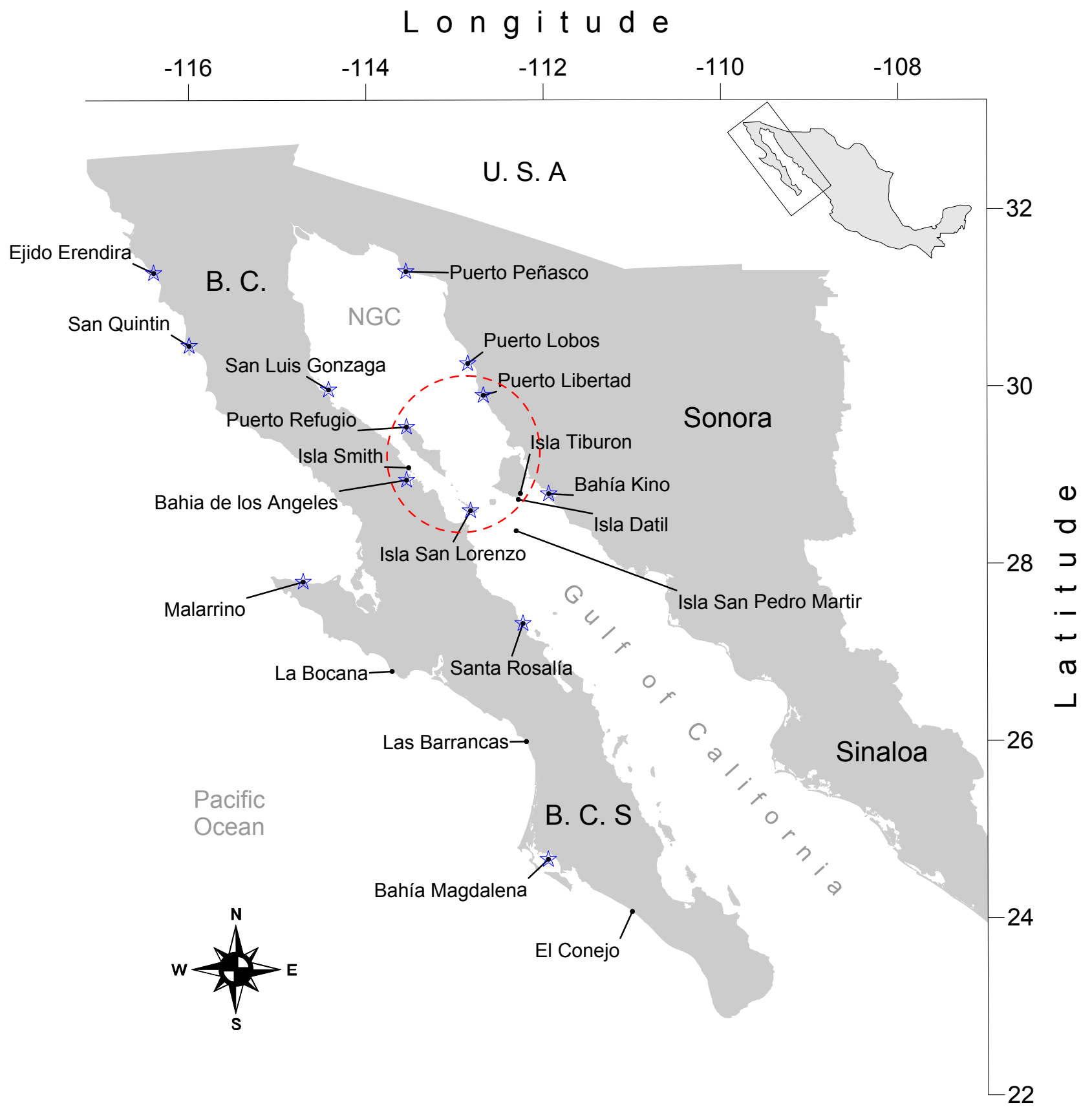




\section{Figure 2 (on next page)}

Genetic assignment of octopus samples from fishing localities in Northwest Mexico to three species.

Locations used for both 16s rDNA and COI are indicated with stars (ê). All locations were used for microsatellites analysis. A) Neighbor-joining trees constructed with 97 haplotypes for both 16s rDNA and COI for $O$. bimaculatus (blue), $O$. bimaculoides (purple) and $O$. hubbsorum (orange). Bootstrap support $>99 \%$ in 1000 replicates are shown for branches separating the three species. B) Bayesian clustering analysis from STRUCTURE showing the probability of individual membership to three genetic clusters ( $K=3,316$ individuals). C) Distribution of octopus species in 20 localities from Northwest Mexico according to phylogenetic and clustering analyses. 
A)

64 Puerto Refugio $(\mathrm{N}=1)$ *

Puerto Lobos $(\mathrm{N}=8)$

Malarrimo $(\mathrm{N}=8)$

San Luis Gonzaga $(\mathrm{N}=8)$

Bahía de los Ángeles ( $\mathrm{N}=7$ )

Puerto Libertad ( $\mathrm{N}=1)$

Bahía de los Ángeles ( $\mathrm{N}=1$ )

$99 \quad$ Bahía Magdalena $(\mathrm{N}=8)$

Ejido Eréndira $(\mathrm{N}=8)$

San Quintín ( $\mathrm{N}=8$ )

73 Puerto Libertad ( $\mathrm{N}=1)$

Isla San Lorenzo $(\mathrm{N}=1)$

100

Puerto Libertad $(\mathrm{N}=1)$

39

Bahía Kino ( $\mathrm{N}=1)$

0.005

Isla San Lorenzo $(\mathrm{N}=2)$

3863 Bahía Kino $(\mathrm{N}=4)$

Santa Rosalía $(\mathrm{N}=2)$

Puerto Libertad (N=2)

31

Puerto Libertad $(\mathrm{N}=3)$

Santa Rosalía $(\mathrm{N}=6)$

26

Bahía Kino ( $\mathrm{N}=3$ )

Isla San Lorenzo $(\mathrm{N}=5)$

B)

\section{Octopus}

hubbsorum

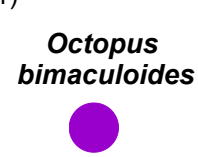

Bahía Magdalena $(\mathrm{N}=8){ }^{86}$

Ejido Eréndira $(\mathrm{N}=7)$

San Quintín (N=8) 65

Isla San Lorenzo $(\mathrm{N}=1)$

Isla San Lorenzo $(\mathrm{N}=1) \quad 53$

Santa Rosalía $(\mathrm{N}=1)$

Isla San Lorenzo $(\mathrm{N}=4) \quad 4$ Bahía Kino $(\mathrm{N}=4)$

Santa Rosalía $(\mathrm{N}=5)$

Puerto Libertad ( $\mathrm{N}=5)$

Puerto Libertad ( $\mathrm{N}=2$ )

Santa Rosalía ( $\mathrm{N}=2)$

Bahía Kino $(\mathrm{N}=4) \quad \square$

Isla San Lorenzo $(\mathrm{N}=2)$
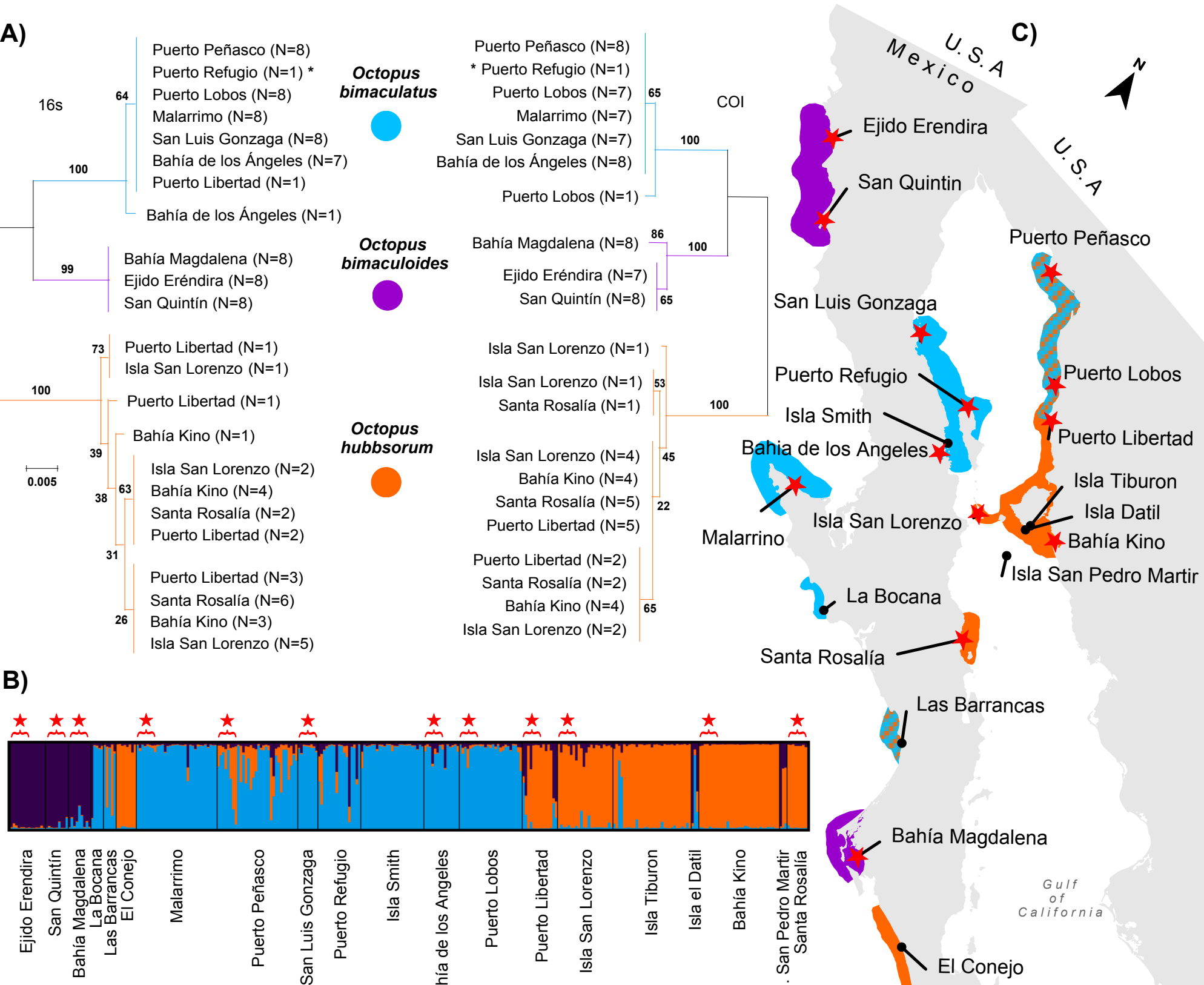

$\stackrel{\star}{\star} \stackrel{\star}{\star}$

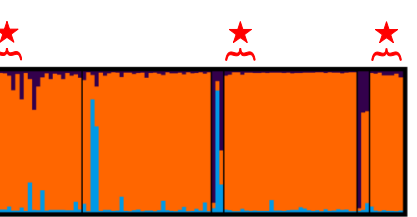

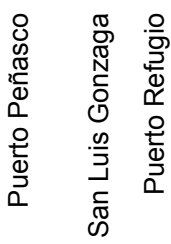

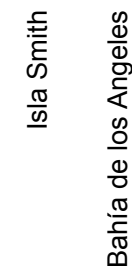

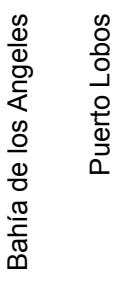

Pacific Coast

North Gulf of California

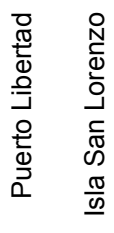

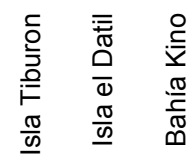

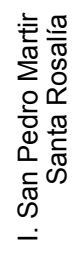

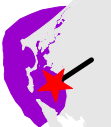

Bahía Magdalena

Samples used for 16S rDNA and COI

Overlap zones

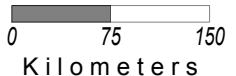




\section{Figure 3 (on next page)}

\section{Relatedness within three octopus species}

Mean pairwise relatedness $(R)$ values ( $\pm 95 \%$ confidence intervals) within three octopus species, compared with bootstrapped upper (Blue) and lower (Red) 95\% confidence intervals assuming random mating (10,000 bootstraps replicates). 


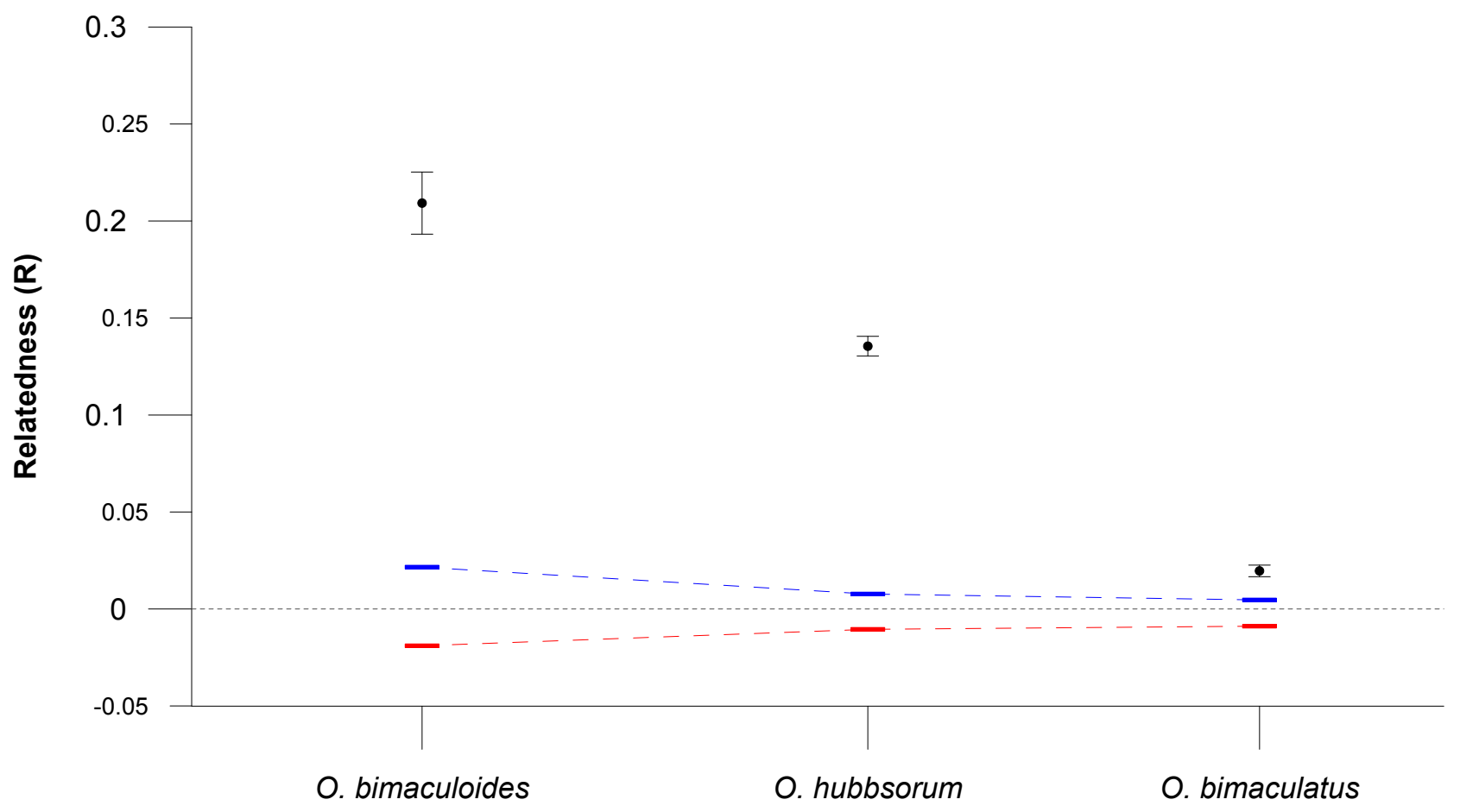

